\title{
Partial state capture by a single oligarchic group: The Gorilla Case in Slovakia
}

\author{
ANDREJ ŠKOLKAY ${ }^{1}$
}

\begin{abstract}
The article discusses the Gorilla case, an officially still-contested partial state capture by a single local oligarchic group, in line with the (partial) Elite Cartels corruption pattern in Slovakia. Due to the manner in which evidence, although considered unofficial, was made available, this case illustrates secret political and business processes during partial state capture. The initial absence of the case in public, political, and academic discourses, suggests that state capture can be present and operate undetected for a long time. This study also shows that in-depth analysis of the Gorilla case was avoided by both domestic and international political scientists, despite its paramount practical and theoretical importance. This, in turn, reflects a methodological capture of political science. Consequently, this article disentangles the complexities of the Gorilla case and lays down the foundation for further studies. Specifically, it highlights the need for more careful research, terminological precision in both theorybuilding and empirical findings on state and media capture based on case studies, as well as reassessment of the methodology of political sciences used in these research areas.
\end{abstract}

Keywords: Gorilla, Slovakia, Oligarchs, Corruption, State Capture, Intelligence Services, Wiretapping

\section{Introduction}

The Gorilla case ${ }^{2}$, an alleged grand corruption case, had its importance downplayed by state authorities and the media (the latter in part being unaware of it), until public demonstrations flooded the streets of the capital of Slovakia a few years later. The anonymous publishing of files code-named Gorila, the Slovak version of the word Gorilla ${ }^{3}$, caused a major political scandal and subsequent public protests which led to dire consequences for the key governmental political

\footnotetext{
${ }^{1}$ Senior researcher, Škola komunikácie a médií, n. o., Handlovská 45, 85101 Bratislava, Slovakia. E-mail: askolkay@hotmail.com

2 Slovenská Gorila: kompletní spis dokumentu (Slovak Gorilla: A Full File), 2012, January 9, https://www.parlamentnilisty.cz/arena/monitor/Slovenska-Gorila-kompletni-spis-dokumentu-221331 3 This codename is not related to the expression "800-pound gorilla" (US English metaphor for a person or organization so powerful that it can act without regard to the rights of others or the law), although it could actually nicely fit in this case. The nickname Gorilla was allegedly in reference to the robust body of a key actor in this case.
} 
party, Slovak Democratic and Christian Union - Democratic Party (SDKÚ-DS). This was timely for critics and opponents of the party, who were concerned about its alleged reliance on dubious party financing - it had been facing significant long-term media criticism. The scandal also created a negative image for several key governing right-wing and centrist political parties as well as Smer-SD (Direction-Social Democracy), the key left-wing political party in Slovakia, shortly before early parliamentary elections in March 2012. The previous governments of Vladimír Mečiar leaned toward a proto-oligarchic regime. The celebrated end of his last government in 1998, however, did not end the associated collusion of politicians and businessmen. A nucleus oligarchic system was still secretly garnering support from the main political parties even after the regime's replacement (see, e.g., Šátek 2010, 2012a).

It was no suprise that leakage of the files via the Internet, and the resultant exposé of the widespread top-level corruption, shook politics in Slovakia. Obviously, this revelation resulted in heightened interest in the media in the scandal. This attention was in contrast to the previous disinterest and prolonged disregard for the case by those who knew about the files - the media, and other entities implicated from conservative estimates, including selected unauthorised individuals and private institutions around the year 2009. ${ }^{4}$ Albeit it was, and is still officially, considered an assumption by the state authorities, the Gorilla scandal has gained notoriety as the most discussed corruption case in the history of the country. The database of SlovakiaOnline, a media content storage company, includes 5,400 mentions of "Gorilla" (+ "SIS" or "case" or "corruption") between December 2011 and July 2014. This is more than three times as many mentions compared to Notice Board Tender, the second most-discussed corruption case with about 1,300 mentions in a much longer period.The Gorilla case demonstrates the dynamics of the covering-up, by politicians and key state authorities, of grand corruption under partial state capture, and the subsequent challenges of uncovering and reporting by the media (the latter discussed separately). The discrepancy between the extent of discussion and the involvement of the media, political scientists and other important stakeholders, provokes arguments which must be assessed from neutral and objective viewpoints. This study also briefly reviews the

\footnotetext{
${ }^{4}$ See no author, 2015, May 21, Prečítajte si list bývalého agenta, ktorý nahrával Gorilu (Read a letter by former agent who wiretapped Gorilla), www.tvnoviny.sk/domace/1793994_precitajte-si-listbyvaleho-agenta-ktory-nahraval-gorilu, A. Hanúsková, 2012, Gorila na roztrhanie. Dzurinda konečne prehovoril... (Gorilla as top agenda. Dzurinda finally spoke out), http://www.noviny.sk/c/ slovensko/gorila-na-roztrhanie-dzurinda-k-nej-vraj-barlicky-nepotrebuje-; 2012, February 1, Policajt z Gorily: Dzurinda ovplyvňoval vyšetrovanie korupcie! (Policeman from Gorilla: Dzurinda put pressure on investigating corruption!), www.topky.sk/ cl/1000120/1297902/Policajt-z-Gorily-Dzurinda-ovplyvnoval-vysetrovanie-korupcie

${ }^{5}$ The Slovak Intelligence Service. The official title in English is Slovak Information Service.
} 
regional situation with regard to state capture and theories of state capture, and suggests that the Gorilla case represents a partial state capture by a single local oligarchic group (in contrast to theories which discuss "cartels" and usually implicitly work with "full" state capture).

Several academic publications have dealt with corruption generally (MungiuPippidi 2013, 2014), regionally (Baboš 2015; Kupka and Mocht'ak 2014; Charron, Lapuente and Rothstein 2013; Grigorescu 2006) and locally, with focus on Slovakia (e.g. Baboš and Malová 2014, Beblavý and Sičáková-Beblavá 2014). However, there remains a vacuum to be filled, until academically relevant, political science publications on the Gorilla case are made. Slovak authors, Staroňová and Malíková (2007), discussed corruption in Slovakia from a political science perspective. However, they mainly tackled grand corruption from the viewpoints of personal patronage, clientelism, and provision of hidden expertise to state authorities by vested interests and regulatory capture - all with limited, if any, local examples. The non-transparent financing of a major Slovak political party, which could indicate the presence of state capture in Slovakia, was mentioned only in a footnote in their study. However, the media reports on non-transparent financing of SDKÚ-DS and other political parties were widely discussed and investigated by the police at the time. ${ }^{6}$ Furthermore, the academic study by Staroňová and Malíková was conducted within the period which commenced when intelligence services tapped corruption practices related to a partial state capture in 2005/2006, and ended when the recordings were made public in 2011. Thus it can be inferred that these political scientists had a distorted analytical focus, because key information was not available to them, although it existed with state authorities and selected top politicians.

Additionally, this study sought inspiration with other resources on the topic. The only specific full-length contribution available, which was conducted by Svoráková (2012), had methodological drawbacks. It gave a relatively unstructured description of the scandal, and a partial description of media coverage of the scandal based on a collection of only about 10 newspaper articles, blog contributions and wire agency reports. Notwithstanding, some observations by Svoráková appear to be correct. There is also a study by Deák (2013a, 2013b) which discussed both verdicts of the courts which initially banned, and subsequently allowed the publication of a novel based on the Gorilla transcripts. Having accessed both reliable and less than reliable sources, the present study emphasizes arguments in favour of understanding Gorilla as a case of partial capture, and highlights surprising analytical ignorance toward the scandal on the part of political scientists. For example, Svoráková's study ultimately cannot be

6 See M. Pisárová (2004, April 1), SDKÚ faces funding scandal, http://spectator.sme.sk/c/ 20022040/sdku-faces-funding-scandal.html 
seen as a serious analytical or descriptive academic case-study contribution to the discussion on the topic, and thus supports the claim about scholarly ignorance.

Attempts made by two journalistic-style books, the first written by one of the two key persons who tried to make this scandal public, Tom Nicholson (2012), and the second by controversial natural scientist and popular novelist, Gustáv Murín (2012), also fall short of filling this vacuum. Nicholson's book is based on transcripts from wiretapping, which he had access to before they were made public. The second book is even less serious, although it covers famous local criminals.

The role of oligarchs in Slovakia has also not been adequately documented, except for two books written by non-academics. The first one, written by a political insider Milan Krajniak (2015), is based on personal memories and journalistic style analyses, without providing any sources. ${ }^{7}$ Even though Krajniak tackles the case considerably, his insider view is relatively compromised due to his own role in the scandal. The other book, written by an investigative journalist Marek Vagovič (2016), is an edited collection of his previously published investigative articles. In spite of concerns regarding their quality, these books provide a foundation for more publications, and should not be ignored. Another worthy mention, a later journalistic study by Obradovič and Petková (2014), which demonstrates some limited share of oligarchs in the national economy, and provides an interesting journalistic overview - based on statistical data - of the possible impact of major oligarchic groups on Slovak economy.

\section{Methodology: Case Study and Discipline Capture}

From a broader perspective, the present paper investigates what the change in political and media importance of the Gorilla case (the latter discussed in detail in a separate paper) reveals about grand corruption under partial state capture. Even though the Gorilla case is of theoretical, political and academic importance, both Slovak and international political scientists exhibited marked indifference towards studying this case. Our study therefore critically analyses the dynamics of the political science framework which nurtured the persistence of this ignorance.

The lack of official evidence about grand corruption represents one possible explanation on why the case was ignored by political analysts, and partially explains why it did not initially receive the nation-wide coverage and importance despite its degree of scandalousness. Yet, our research questions the reliability of results from the official investigations of state authorities, under partial or full state capture. Consequently, the (partial) capture of the media, partial or full (depending on definition and available evidence) state capture, as well as the methodological capture of political sciences represent a better ground for a sound conclusion on

\footnotetext{
${ }^{7}$ On this case, see for example J. Boyd, 2012, June 1, Former MP Charged with Corruption in "Notice Board" Tender, The Daily Slovakia www.thedaily.sk/former-mp-charged-withcorruption-in-notice-board-tender/\#ixzz48WWUlAPj
} 
why all the major stakeholders ignored the case. This means, in other words, that wide public attention to the case as well as in-depth academic research in spite of missing official evidence, might have led to substantial impact on political life and/or relevant findings on state capture in a country. This is why an analysis of the possible (broadly understood, partial or full) capture of the stakeholders politicians, state authorities, media and political scientists - is essential.

This paper is meant to facilitate further debate and provide specific analytical insights, and thus deals primarily with the possible capture of the political sciences; the case of capture of the media and other key stakeholders will be dealt with in a separate article (or by other authors). The capture of the political sciences is defined as the lack of interest in research and in-depth documentation of specific case studies, or the ignorance of available indicators due to the lack of officially confirmed and truthful evidence, which is supposed to have been produced by captured state authorities. According to Box-Steffensmeier, Brady and Collier in The Oxford Handbook of Political Methodology (2009), political science methodology emphasizes three issues: utility for understanding politics, pluralism of approaches, and cutting across boundaries. The present case study, if deepened and extended, could be useful for understanding contemporary politics and drawing comparative lessons - especially as regards some of the core issues such as the role of the media, corruption. The requisite methodology and findings made could also prove relevant for other scientific disciplines - in other words, it would cut across disciplinary boundaries. Accordingly, it is surprising that a detailed examination of this case of grand corruption and state capture has been mostly ignored by political scientists - unless the analytical function of political science is only possible when researchers have access to data already verified by the state authorities themselves, which would however be an absurd situation. The lack of relevant studies raises a number of research questions. It is impossible to tackle all of them here; nevertheless, the sheer number of these questions suggests the failure of political science. Therefore, priority is given to introducing these potential research questions within context of an intrinsic or explanatory-evaluative case study. It should be noted that case studies are both theoretically and methodologically diverse and relatively subjective. According to Remler and van Ryzin (2015), the case-study approach adopted in this paper qualifies as a typical critical case. This type of case study emphasizes characteristics which have theoretical or practical significance. From Stake's (2005) perspective, the paper can be considered an intrinsic case study, which is characterised by a holistic approach to a single case. In Yin's categories (2013), this study's approach qualifies as an exploratory-evaluative case study attempting at an exploratory, indepth analysis, and at describing the underlying complex interactions of the processes which governed the Gorilla case. It is also possible for types of case studies to overlap each other. The methodology of this work can thus best described as an intrinsic, critical, exploratory-evaluative case study. 
There is also disagreement in literature on the use of theory in case studies. Stake (2005) argues that theory can be absent from case studies which focus on describing the case and its issues. Yin (2013) claims that theory can be used to guide the case study in an exploratory way. Creswell (1994) asserts that theory is employed toward the end of the study providing a "theory-after" perspective in which other theories are compared and contrasted with the theory developed in the case study. The current case study employs, to the extent that they are applicable, the theory of cartels, as well as the concepts of "oligarch" and "state capture" which together suggest a grand corruption scenario.

By the means of a case study, this paper raises a number of challenging research questions and reveals possible analytical lessons to be learnt about the widely discussed yet under-analysed case of alleged grand corruption and state capture in Slovakia. Since the key salient issue is why this case was ignored by all major stakeholders in general, and political scientists in particular, some general introduction into the importance of the case is necessary. However, we will initially present three important relevant methodological sub-questions. These subquestions highlight and justify the analytical importance of the case, without the need to dig deeper into the details. (1) The first sub-question is related to the initial assessment on whether there was a state capture and what type of state capture we found. (2) Second, and more importantly, we discuss how one can analyse state capture under these unique circumstances. (3) The third sub-question investigates (and questions) the analytical relevance of the theory of cartels, as the only available relevant theory for such examination, in relation to state capture and grand corruption.

(1) The first methodological sub-question is concerned with the extent to which one can assume that there was a state capture, and which type of state capture occurred if the answer to the former is in the affirmative. The text indeed answers the question in the affirmative by arguing that a partial state capture which is not a commonly used term in related theory of state capture - occurred. It is true that World Bank experts (Hellman, Jones and Kaufmann 2003) as well as other experts (including Philp 2001; Fazekas and Tóth 2014) attempted previously to distinguish different levels and methods of state capture. Nevertheless, the majority of recent studies in political science (including Keil 2018; Innes 2014) approach state capture from a broad perspective. It is also true that partial state capture is a common situation; for example, it is currently widely discussed in many post-communist countries and South Africa.

(2) Consequently, as regards the second sub-question, this case is approached in a manner which will provide palpable evidence, although mostly indirect and unofficial, on how partial state capture has operated before. The study also assesses the complex interactions between key players or captors, that is, politicians, state authorities, and investigative bodies. It hypothesises, and tries to support the claim, that there can be a successful cover-up of grand corruption, by 
means of partial state capture. In other words, captors may have direct or indirect control over state authorities who are supposed to investigate the state capture. Consequently, the study explores the possible exploits of captors, and the corollaries thereof, using a common reference scenario: When evidence is revealed publicly, official investigation may take years, and involved actors may successfully use legal means to prevent the use of crucial evidence. The study presents an independent analysis of the case, on the premise that academic jurisdictions are not limited by legal restrictions on the use of evidence. In lieu of the possible risk that independent analyses can turn out to be incorrect, especially due to the complexity of cases like the Gorilla and a lack of officially recognised evidence, the conclusions presented in this paper are reached by examining a wealth of evidence from (non-academic) sources. The selection of these sources was determined content-wise; the qualifying criteria concerned the relevance and logic of arguments used by the key actors; actions performed by state authorities or their revealing indifference prior to the case going public, or after that, as well as contradictions in their statements or follow-up steps -; silence of politicians on the issue before making the scandal public or inconsistent answers afterwards. These make the bulk of analytical evidence used for situating the case in the relevant intrinsic, critical, exploratory-evaluative case study framework.

The use of written evidence - summary of transcripts about high-level corruption talks -, although not legally valid, has been justified by the statements by the former head of the special police investigations unit, who confirmed that the operations described were mostly verified during investigation. The use of anecdotal evidence, such as personal public testimonies, was also justified by reliability indicators of persons interviewed: the former head of the special police investigations team and a former counterintelligence agent.

(3) The third methodological sub-question concerns the relevance of the theory of cartels in relation to state capture and grand corruption. The study presents the argument that there was a single "cartel" which was documented in the Gorilla case, and accordingly attempts to support the claim that it was a partial Elite Cartel pattern of grand corruption. This is approached from a perspective which creates a contrasting scenario of a full state capture by Elite Cartels. Furthermore, we briefly discuss the problematic use of the term "cartel".

\section{The Development of the Gorilla case}

In order to make up for the lack of relevant academic literature on the Gorilla case, we now present an overview of its development. Due to space limitations, we cannot provide a full discussion; therefore only the major points of the case are covered. The story is known to local experts and is frequently (although briefly) mentioned in political and media discourses. However, explanations may differ and 
the memories of the key events, persons, actors and proper chronology, die away or become blurred with time.

What has become known as "the Gorilla case" had its origin in the late months of the year 2005 and early months of the following year. Since then, the case has been ongoing for over a decade. However, it became publicly known only six years after its origin, even though evidence exists which shows that some state authorities were aware of it already in 2005 and 2006. The aforementioned lengthy Gorilla document emerged shortly before Christmas in 2011 on an international website, with summaries of fake or real (depending on the perspective of a reader) transcripts of private conversations between some top and lower-level public and private figures. ${ }^{8}$ Obviously, intelligence services never officially confirmed the veracity of the leaked file. The published file was supposedly compiled by the Slovak Intelligence Agency (SIS). The fact that the SIS monitored a particular apartment during that particular period has been confirmed by the court which had initially permitted wiretapping, although another court later declared it illegal.

The persons involved in the file discussed privatisation deals conducted or planned during the second term of the government led by Mikulás Dzurinda, a reformist Prime Minister who held office between 1998 and 2006. ${ }^{9}$ The allegations that bribes worth millions of Euros were paid or promised to public or party officials, politicians and/or political parties to win various public procurement and privatisation contracts lie at the heart of this scandal. Several ministers of government, representatives of multinational organizations, all four political parties in Dzurinda's second coalition government, and tycoons from Penta Investment Group - one of the largest Slovak private equity investment groups - were implicated as well. Moreover, illegal activities of other important politicians and political party nominees were mentioned during the conversations. These conversations were accidentally ${ }^{10}$ - though as mentioned above, upon initial court's permission - recorded in 2005 and 2006 in an apartment. It is presumed that the first civil person to gain access to the file was Tom Nicholson, a BritishCanadian journalist naturalised in Slovakia. In 2009, he tried to contact the media and police with the information. However, editors of the newspaper Sme and business weekly Trend did not dare to publish this information on the assumption

\footnotetext{
8 Slovenská Gorila: kompletní spis dokumentu (Slovak Gorilla: A Full File), 2012, January 9, https://www.parlamentnilisty.cz/arena/monitor/Slovenska-Gorila-kompletni-spis-dokumentu-221331 ${ }^{9} \mathrm{He}$ also was Minister of Foreign Affairs in Iveta Radičová' s 2010-2012 government.

10 The agent of SIS lived in the same block of flats in which meetings were held. He informed his superiors about suspicious visits of some high-ranking persons around, and the court gave initial permission to wiretapping; see Valček (2016), although Škubla (2016), concluded that the Constitutional Court banned any legal use of transcripts of recordings from the Gorilla case in its Statement III. ÚS 490/2015. Even earlier, the Constitutional Court had cancelled previous court's permission allowing wiretapping operation and called it unconstitutional, on November 20, 2012.
} 
that there was inadequate evidence, although the police had started to deal with the case in two independent investigations (Kostolný 2012a). ${ }^{11}$ The extent to which the material published online can be considered genuine, and a valid match to the official documentation of the SIS, remains debatable (Nôta 2015). Some analysts consider it authentic evidence - Svoráková (2012: 2) considers it partially authentic, while Šátek (2012a; 2012b) seems to consider it fully authentic. Paradoxically, Nicholson, the key mover behind the scandal, raised doubts about the introductory and concluding parts of the document (Hanus and Vagovič 2012). However, there are only few doubts about the fact that the information described in the file reflects a true depiction of how politics and big businesses secretly interacted in Slovakia (see Sátek 2012a, 2012b; also interviews with M. Gajdoš, the [former] head of special police investigating team, in Vagovič 2017; and Tódová 2017).

Nicholson mentioned three reasons why he believed the Gorilla file was trustworthy. Firstly, every major issue included in the file subsequently happened the way it was mentioned, with just minor irrelevant variations. Secondly, every person from SIS with whom he spoke confirmed the relevance of the file; nobody said it was nonsense or unauthentic, except the people themselves involved in the corruption scandal (Nicholson 2012). Thirdly, the former Prime Minister Iveta Radičová took the last existing intelligence summary of the Gorilla case, deposited in the Government Office, and gave it to the state authorities responsible for investigation, even though she did so only after the scandal became public (Klačanská and Mezencová 2012). Again, the data anonymously published in the late part of 2015 suggested that some events described in the file were most likely based on facts. ${ }^{12}$ Furthermore, the sitting Prime Minister at the time, Robert Fico, stated with regard to Gorilla: "...if there would be successful investigation, we would learn facts about the second Dzurinda government that would cause goose bumps" (Pravda, November 19, 2016, p.2). At about the same time Marek Gajdoš, the head of the special investigation team, announced his resignation. The resignation is believed to have been partly caused by internal conflicts within the investigation hierarchy, especially when the supervising special prosecutor seemed to be holding up the investigation instead of helping it proceed. Nevertheless,

${ }^{11}$ P. Bielik and B. Oprala (2016, April), Tom Nicholson: Vyčítali mi, že som blázon bojujúci proti systému (Tom Nicholson: They criticised me for being a fool fighting the system), http://gaudeo.sk/tom-nicholson/, see June 15, 2015, https://dennikn.sk/minuta/160519/; 2012, January 17, PROKURATÚRA: Preskúmali kauzu Gorila zákonným spôsobom a nestranne (The Office of the Prosecutor: They investigating the case Gorilla according to law and impartially), http://ipolitika.sk/2012/01/prokuratura-preskumali-kauzu-gorila-zakonnym-sposobom-anestranne/

12 See the video from press conference by journalist Marek Vagovič and lawyer from an NGO Zuzana Čaputová, 5 November 2015, www.tyzden.sk/video/27851/potvrdili-pravost-casti-spisugorila/; also Daniš (2015); but see also the counter-arguments by Penta in Durík (2015). 
Gajdoš once again confirmed that the majority of facts mentioned in the file had been verified as accurate during the investigation. Gajdoš explained that this type of corruption is difficult to investigate, which is why criminal consequences for perpetrators were unlikely in the few years following the events - according to Gajdoš, investigation had to start immediately, in order to achieve punitive effects (interviews with Gajdoš in Tódová 2017 and Vagovič 2017; see also Wágner 2017 on the controversial role of supervising authorities). Another important issue is the leakage of the Gorilla file on the Internet. Without this anonymous publishing, there wouldn't have been the nationwide scandal surrounding the case. It is still unknown how the classified information was leaked to the public and who initially published the Gorilla file on the Internet.

The fact of media apathy during the period cannot be overstated. Some editors as well as top- and low-level politicians knew about the Gorilla case a few years before it was made public. ${ }^{13}$ However, media organizations avoided publishing or broadcasting excerpts from this file due to their fear of follow-up libel suits. Nevertheless, it is important to note that some media outlets did not know about the file. ${ }^{14}$ In any case, no politician pushed for the investigation of the scandalous case before the case became publicly known. Some independent observers, politicians, politically appointed civil servants, and later also Gajdoš, claimed that the SIS itself had shown a lack of interest in cooperating toward the examination of the files and the case (Nicholson 2012; interview with Gajdoš in Tódová 2017). Others, including the former head of SIS, blamed the police or state prosecutors for a lack of true interest in investigating the case (see Mihočková, 2015). Perhaps both claims are correct. The scandal remained partly hidden for a long time, and other directors were appointed for the stakeholder institutions. Jozef Šátek (2012b), former director of Anti-corruption Authority, argued that the initial lack of interest in investigating the case could have occurred due to forthcoming parliamentary elections which were scheduled in 2010 (see also Čikovský 2017). The dubious role of Dobroslav Trnka, another state representative, was revealed when he personally raised serious doubts about the authenticity of the file and attempted to push for the Gorilla case to be investigated directly through the Prosecutor General's Office, while acting as Deputy Prosecutor General. The Minister of Interior Daniel Lipšic finally established a special team to investigate the Gorilla case in January 2012, and

\footnotetext{
13 See No author, 2015, May 21, Prečítajte si list bývalého agenta, ktorý nahrával Gorilu (Read a letter by former agent who wiretapped Gorilla), www.tvnoviny.sk/domace/1793994_precitajtesi-list-byvaleho-agenta-ktory-nahraval-gorilu; A. Hanúsková, 2012, Gorila na roztrhanie. Dzurinda konečne prehovoril... (Gorilla as top agenda. Dzurinda finally spoke out), www.noviny.sk/c/slovensko/gorila-na-roztrhanie-dzurinda-k-nej-vraj-barlicky-nepotrebuje-; 2012, February 1, Policajt z Gorily: Dzurinda ovplyvňoval vyšetrovanie korupcie! (Policeman from Gorilla: Dzurinda put pressure on investigating. www.topky.sk/cl/1000120/1297902/Policajt-zGorily--Dzurinda-ovplyvnoval-vysetrovanie-korupcie-

${ }^{14}$ As stated above, media coverage and attitudes are dealt with in a separate paper.
} 
several politicians called for a thorough examination of the claims contained in the file.

As of the publication of this study, the slow (see Šatek 2012c) but extensive (see Vagovič, 2015) ${ }^{15}$ official investigation of the case by the state authorities is still ongoing, although Dušan Kováčik, the special prosecutor, claimed in May 2016 that the investigation was about to be completed (Ducár 2016).

There was a contrast between the public's as well as media interest in learning more about the case, and attempts by the main private-commercial actor to downplay it. On the one hand, an eruption of media coverage occurred in relation to this case, along with politicians struggling to issue statements in an endeavour to withstand politically the scandal, protests and other forms of pressure from the discontented public. Public and media interest in this case was renewed after a new round of leaks, code-named by the media as "Gorilla II", which occurred in late 2015 and concerned indirect high payments from Penta Investment Group to a company belonging to the former head of the counter-intelligence unit of SIS, (see e.g. Tódová 2015b). ${ }^{16}$ On the other hand, Penta Investment Group as the main private "antagonist" mentioned in the file exerted a lot of $\mathrm{PR}^{17}$ and legal counter-effort ${ }^{18}$ into tackling this issue. All this highlights the need for more detailed focus on the role of oligarchs in politics and the economy in general, either in Slovakia or other post-communist countries.

\section{Theoretical Ramifications: Slovakia as a Case of Partial State Capture by Oligarchs}

The Gorilla files present a good model for how local oligarchs subordinate politics and the economy to their own interests. In other words, this case deals with possible grand corruption ${ }^{19}$, partial state capture ${ }^{20}$ or partially appropriated state ${ }^{21}$.

15 The Special Prosecutor (who deals with organised crime and other forms of especially serious crime) Dušan Kováčik, claimed that the police file on investigation of Gorilla had 60,000 pages, police conducted 650 interviews, and asked 12times for legal help from abroad and initiated 20 criminal proceedings as of June 2015. However, interview with the key witness - former SIS agent Holúbek, was done only in summer of 2016, but rather formally and without going into substantial issues, and under unusual conditions (see interview with Gajdoš in Vagovič, 2017, and interview with Holúbek, in Cuprík, 2016).

${ }^{16}$ For the original transcript see http://skgorila2.tumblr.com/

17 See www.kauzagorila.sk and www.pentaokauze.sk/ According to the intellinews, September 22, 2014, Penta had 3,000 mentions at the height of the Gorilla scandal. Jaroslav Hašćák claimed that the Gorilla case was a PR disaster but mostly in Slovakia, less so in the Czech Republic or Poland, and there was almost no impact of this scandal in Germany (in Haluza, 2013).

18 See for example the letter by legal representatives of Penta sent to various websites, www.ginn.press/news/hascak-penta-utocia-na-gorilu or Valček (2015a) and Burčík, (2016).

19 "Grand corruption" by political and business elites involves the payment of bribes to gain contracts but also the purchase of political influence. In contrast, "petty" corruption is when people are expected to pay bribes in order to get the service they are entitled to from a public 
A discussion on the complex relationship between oligarchism and state capture is necessary. This is emphasized by the observation by Maniokas (2014) that the issues of corruption and state capture are no longer deviations; instead, they have become the norm. The modern oligarchic system is broadly considered as a concealed political and business regime based on corruption (Johnston 2005). The European Union Regional Anti-Corruption Initiative defines state capture as the phenomenon in which outside interests are able, through corrupt transactions with public officers and politicians, to bend state laws, policies and regulations to their benefit (Bell 2010: 1). Even though this is the most common definition, other definitions are worth considering. Calus (2015) defines state capture as a process of subordinating state institutions to the leaders of the political parties. Consequently, the argument is acceptable that in all such cases we may deal with grand corruption or state capture which is fuelled or nurtured by political and business elites in both democratic and non-democratic states, regardless of whether these states are rich or not (Porta and Vanucci 1999). Whatever definition is used, state capture is seen as the most destructive and intractable corruption problem, particularly in transitioning economies (Bell 2010: 1). ${ }^{22}$

Johnston (2005) identified four syndromes or patterns of corruption ("Influence Markets," "Elite Cartels," "Oligarchs and Clans," and "Official Moguls") which correspond to four ways of combining politics and economics, as well as the quality of public economic and financial institutions. Of these four syndromes, the partial Elite Cartels system presumably operated at the time of incidence of the Gorilla case within Slovakia, and the entirety of developments behind the Gorilla scandal seem to confirm this hypothesis. The specification "partial" is used to emphasize the involvement of a single cartel, the Penta Investment Group - although "cartel" may not qualify as the best analytical term in this scenario. However, this does not preclude that there could be more cartels or, more appropriately, oligarchic groups which were operating in a similar way in

employee. The Anti-Corruption Research Centre defines high level or grand corruption as corrupt acts that take place at the policy formulation level of the political system. It refers not so much to the amount of money involved as to the level at which it occurs - where policies and rules may be unjustly influenced. The UN Office on Drugs and Crime (UNODC) Anti-Corruption Unit defines grand corruption as corrupt acts that often involve prominent persons in both the private and public sectors who exercise influence over large government contracts (Bell 2010: 1).

20 The concept of state capture was introduced by Karklins (2002) and Hellman, Jones and Kaufmann (2003) to describe some aspects of economy transition in some of the former communist countries of Eastern Europe. In this transition, some companies were deliberately adopting strategies of networking to influence government officials and politicians to change the laws and regulations in their favour, and partly accomplished it through corrupt payments, although Karklins understood this concept more broadly (see more in Naxera 2015).

${ }^{21}$ See Figure 1: Typical network configurations of corruption and state capture in Fazekas and Tóth (2014).

22 See more in Transparency International (2014): State capture: an overview, https://www.transparency.org/files/content/corruptionqas/State_capture_an_overview_2014.pdf 
Slovakia at that time. ${ }^{23}$ Notwithstanding, a measure of state capture should be based on the extent to which the state's decision making is distorted by the illicit influence of powerful firms, and not necessarily on the number of firms actively exerting such influence (World Bank 2000). A study by Steves and Rousso (2003: 14) suggested that the state capture index of Slovakia was similar to the worst half of Central East European states in 1999 (i.e after the fall of Mečiar's regime) and during the first year of Dzurinda's first reformist government.

The "state capture index", in the study by Steves and Rousso, refers to the unweighted average of countries' scores on six components of state capture, including firms' influence over the government, parliament, criminal and commercial courts, central bank, and political parties. According to this study, Slovakia's state capture was less significant than that of Bulgaria, worse than that of Romania, and almost identical with those of Bosnia and Herzegovina. Ironically, Slovakia performed above average in almost all monitored anticorruption parameters: Intensity of Anti-Corruption Index, Omnibus Index, Legal Framework Index and Conventions Index. In the majority of these anticorruption activity indices from 1999-2002, shortly before the Gorilla case was wiretapped, Slovakia was among the top countries or best achievers (Steves and Rousso 2003: 9). In other words, prior to the Gorilla case Slovakia demonstrated commendable results on various anti-corruption measures. Nevertheless, this did not have any impact on the behind-the-scenes grand corruption and state capture events, as described in the Gorilla file. This is in itself an important and intricate finding. The measures may not depict the realities of corruption. Consequently, the assertion that this poor state of affairs probably persisted even after the Gorilla scandal could be valid. Innes (2014) argues that most new EU Member States, mostly post-communist states, experience serious problems of state capture. Innes suggests that states like the Czech Republic, Slovakia, Romania, Bulgaria and Latvia show high levels of "corporate state capture" in which public power is exercised primarily for private gain. Alwasiak et al (2014) found that in Poland, the majority of legal acts were passed with the aim to satisfy the interests of particular groups and this continually increased over the years. Nevertheless, the state capture through the oligarchic system in new EU Member States is not as developed as, for example, in neighbouring Ukraine, where the "oligarchs and clans" syndrome can be found (Matuszak 2012; Olszański 2017). However, there are cases of similar, more likely full, state capture syndromes among other South Eastern European states (see e.g. Keil 2018).

\footnotetext{
23 See e.g. the list of alleged local oligarchs in Konštantín Čikovský (2015, March 11), 10 investigatívnych žurnalistov pomenovalo 5 najväčších oligarchov (10 investigative Journalists named five most important oligarchs), https://dennikn.sk/69130/10-investigativnych-zurnalistovpomenovalo-5-najvacsich-oligarchov/
} 
In consequence, examples of state capture can be identified as bribery, "ownership" of politicians, control of regulatory agencies - in this particular case, a privatisation agency called National Property Fund - which does not involve violence and intimidation originating from oligarchs (Philp, 2001). At least, this was true until Ján Kuciak, a data investigative journalist, was murdered in early 2018. This is not an assertion that Kuciak was killed on order by oligarchs; instead, it points out that his journalistic investigation threatened somebody's grand-size illegal profit-seeking activities. In other words, independent investigation was seen as a bigger threat than investigation which was sanctioned by state authorities. In that regard, this murder could be regarded as a turning point in the modern history of Slovakia. Again, Kuciak's case deserves to be covered in a separate case study. It is also worthy of mention that Slovak journalists faced intimidation even before this murder, but violent threats did not originate from local oligarchs. Instead, local oligarchs used legal means to harass and intimidate them.

It is likely that this form of partial state capture did not have a strong immediate impact on economic growth in Slovakia. According to Damijan and Damijan (2017), corruption is shown in some regions to affect growth through state capture activities, while in others it is shown to have a negative impact in the long-run rather than in the short term. It can be assumed that partial state capture did not last long enough, and did not involve major sectors of the economy, to have a strong effect on the Slovakian economy. The Slovak GDP grew between 2001 and 2005 by about 4\% annually (Okáli 2006: 6). However, another question arises pertaining to whether the GDP growth could be higher without state capture in the long-term.

\section{Conclusion}

After more than thirteen years of existence and seven years after its publication, the Gorilla case remains as an unresolved high-profile national political scandal (see Penta Investments 2016 or Burč́k 2016). Unexpectedly, the media reported in December 2018 that the Police had found audio-recordings of SIS wire-tapping operation in the safe of a businessman seen as responsible for various alleged criminal activities including, possibly, the already mentioned murder of investigative journalist Kuciak. This could mean a turning point in the Gorilla case. This finding was not directly related to the investigation that was still ongoing during the writing of this study. Although the key police investigator publicly confirmed the authenticity of the events described in the file (interview with Gajdoš in Tódová 2017; Burčík, 2015; see also Čikovský 2012; and counterarguments by Penta ${ }^{24}$ ), no court verdicts have been passed so far. ${ }^{25}$ However, it

${ }^{24}$ See Penta (no date): Transakcie v spise (Transactions in the file), www.pentaokauze.sk/sk/ articles.aspx?r $=34 \mathrm{mPCE}$ 
was a significant development that the police initiated four new criminal charges related to the Gorilla case in $2017 .{ }^{26}$ It appears that the file correctly described corrupt negotiations and deals between politicians and the oligarchic investment group, considering all the evidence and circumstances analysed. ${ }^{27}$ This is further supported by the sharp and systematic reactions, including both legal and PR efforts of the Penta Investment Group. For example, Penta issued a legal request demanding that the recordings found in the safe of jailed businessman in December 2018 be destroyed. Yet, Penta Investment Group could not know the precise content of these recordings.

Thus, this preliminary, and probably final, assessment of veracity of Gorilla scandal is rather important - if the narratives from the file were all fabricated stories, the media could be seen as misleading the public. Consequently, the Gorilla case would become the biggest media hoax and fake scandal in the history of Slovakia. However, the eagerness which Penta Investment Group demonstrated toward the ban on the use of "fake" recordings, or recordings of unknown content cannot be simply overlooked. If we look for some positive upshot of the Gorilla case, we could say it ultimately provided a platform through which the public learnt in general terms about hidden business and political practices which amounted to a form of partial state capture by a single local "cartel". Because a single oligarchic grouping was documented in the case, we have a reason to claim that Gorilla case indeed followed a partial Elite Cartels pattern of grand corruption, in contrast to the scenario when a full state capture by Elite Cartels emerges. This conclusion does not preclude the possibility of such a development in Slovakia, for which the present study has not found sufficient evidence. We have also corroborated the conjecture that the local judiciary, police, and especially state prosecutors may not be reliable sources of information on the real state of affairs, especially in cases of grand corruption under (partial) state capture and/or (partial) media capture. Police investigators may start investigations too late, without the needed support and serious commitment from supervisory and other key authorities. Similarly, the judiciary may be limited in

\footnotetext{
25 See related criminal charges to one of privatisation deals, Kauza Slovenských elektrární: Polícia vzniesla nové obvinenie (The Cause of Slovak Power Plant: Police has raised new charges), at www.maplefish.sk/kauza-slovenskych-elektrarni-policia-vzniesla-nove-obvinenie/, March 12, 2016. The very first criminal charges directly related to Gorilla were raised but also immediately cancelled in 2012, see Prokurátor zastavil trestné stíhanie Pavla Ruska (Prosecutor Stopped Criminal Investigation of Pavol Rusko), (March 15, 2012), www.noviny.sk/c/slovensko/ prokurator-udajne-zastavil-trestne-stihanie-pavla-ruska

26 http://www.tvnoviny.sk/domace/1876670_styri-nove-stihania-v-kauze-gorila, July 1, 2017

27 See for example, Malchárek z Gorily dostal po odchode z politiky milióny. Od podozrivej firmy s cyperskými vlastníkmi (Malchárek from Gorilla obtained millions after he left politics. He got this money from a suspicious company with Cypriot owners), December 10, 2015, www.aktuality.sk/clanok/309885/malcharek-z-gorily-mal-po-odchode-z-politiky-dostat-milionyod-podozrivej-firmy-s-cyperskymi-vlastnikmi/
} 
their search for justice by means of procedural rules. The processes which are utilised to validate evidence can easily become bureaucratic and unable to achieve the desired goals.

The Gorilla case, in a manner similar to numerous information-leak cases worldwide, demonstrates that the modern digital environment makes it rather difficult for corrupt networks to maintain deep secrecy. On the other hand, these corrupt networks may prevent, postpone, and complicate investigations of some of these cases. They are capable of meddling with the legal framework to such an extent that the cases became obscure and impossible $t$ resolve, all the while the pieces of evidence are becoming marked as legally irrelevant by courts, or even disappear altogether. The influence of some state representatives and their willingness to protect their vested interests provide favourable circumstances for such phenomena to occur. Their links to the government further complicates the proceedings, because any discrepancies may be blamed on governments and relevant authorities, instead of the blameworthy individuals.

This study identified a triple paradox within the Gorilla case. Firstly, the unofficial watch-dog which is the media did not initially want to deal with the case, or was uninformed about the file. The reasons for this lack of coverage and specifics of the media environment at that time will be discussed in a separate article. Secondly, from the point of the liberal democratic ideal of checks and balances, it was disconcerting to realize that official state authorities attempted to downplay this case as well, absurdly blaming each other for the initial failure of investigation and lack of mutual co-operation. Thirdly, neither domestic nor international political scientists engaged in an in-depth study of the Gorilla file as well as analysis of the resulting political and social events. Domestic journalists and non-fiction writers had to take the mantle and supplement their work. We suspect that the absence of timely and reliable analyses of such important if legally unresolved phenomena, which often result from the analysts' heavy reliance on media and political discourse, and subsequent sub-optimal analytical focus on the part of political scientists, might contribute to recurrence of such developments in the future.

The study demonstrates that cases of grand corruption provide opportunities for research into the complex dynamics which govern the corrupt relationship between business and politics, and how these can negatively impact the stakeholders who have been entrusted with the responsibility of enforcing the integrity of public authorities and the management of national resources. There is much left to be covered on the related conceptual, terminological and methodological aspects of such cases. There is also a vacuum to be filled regarding research on the roles of various stakeholders involved in grand corruption cases. 


\section{Bibliography}

Note: Access to online documents has been checked as of November 1, 2018.

Alwasiak, Stanislaw, Monika Lewandowska-Kalina, Lech Kalina and Krzysztof.I. Rybinski (2013): “What Determines State Capture in Poland?” Management and Business Administration, Central Europe 21(4): 86-109.

Baboš, Pavol (2015): 'Corruption Experience, Perception and Anti-Corruption Trust: Different Effects in Various Post-Communist States." Romanian Journal of Political Science 15(1)

Baboš, Pavol and Darina Malová (2014): "Losing Jobs in Crisis: Impact on Corruption Experience. Perception and Trust in Fighting Corruption." Raziskrave in Ra:prave (Research and Discussion) 7(1): 83-112.

Beblavý, Miroslav and Emília Sičáková-Beblavá (2014): “The Changing Faces of Europeanisation: How Did the European Union Influence Corruption in Slovakia Before and After Accession?" Europe-Asia Studies 66(4): 536-556, DOI: 10.1080/09668136.2014.899767

Bell, Allan (2010): Literature Survey on State Capture, Grand corruption \& political corruption 1995-2010, World Bank, on-line (http://siteresources.worldbank.org/ PUBLICSECTORANDGOVERNANCE/Resources/285741 -

1315337528748/LitSurveyAnticorruptionStateCapture.pdf)

Box-Steffensmeier, Janet M., Henry E. Brady and David Collier, editors (2009): The Oxford Handbook of Political Methodology, DOI: 10.1093/oxfordhb/ 9780199286546.003.0001

Burčík, Matús (2012, February 3): "Súd vyhovel Pente, Nicholsonovu knihu o Gorile stopol. (The Court Upheld the Penta and Banned Nicholson's Book About the Gorilla.)" Sme, on-line (http://www.sme.sk/c/6244527/sud-vyhovel-pentenicholsonovu-knihu-o-gorile-stopol.html)

Burčík, Matúš (2011): "Fico nepoprel záznam z Gorily. (Fico Hasn't Denied the Recording from the Gorila file.)" Sme, December 29, on-line (http://www.sme.sk/c/6198332/fico-nepoprel-zaznam-z-gorily.html)

Burčík, Matúš (2013): “Odpočúvaní Nicholsona uniklo viac, na webe sú nahrávky so šéfom pit'ovcov. (More of Nicholson's wiretappings slipped away, the recordings with the mafia boss are on the Internet.)" Sme, November 5, on-line http://www.sme.sk/c/6995660/odpocuvani-nicholsona-uniklo-viac-na-webe-sunahravky-so-sefom-pitovcov.html

Burčík, Matúš (2015): “Polícia pripúšt'a pravost' Gorily, pokračuje vo vyšetrovaní. (The Police admits the authenticity of Gorilla and continues with the investigation.)" Sme, February 1, on-line (http://www.sme.sk/c/7621928/policia-pripusta-pravost-gorilypokracuje-vo-vysetrovani.html)

Burčík, Matúš (2016): “Haščák sa na súde domáhal, aby zakázal parlamentu rokovat' o Gorile. (Haščák Has Asked the Court to Ban the Parliament to Discuss the Gorilla Case.)" Sme, May 25, on-line (http://domov.sme.sk/c/20173063/hascak-sa-na-sudedomahal-aby-zakazal-parlamentu-rokovat-o-gorile.html\#ixzz49k22zCYF)

Calus, Kamil (2015): “A captured state? Moldova's uncertain prospects for modernisation." OSW Commentary 168, Centre for Eastern Studies, Warsaw, on-line (www.osw.waw.pl) 
Creswell, John (1994): Research Design: Qualitative and Quantitative Approaches. CA, Thousand Oaks: Sage.

Cuprík, Roman (2016): “Holúbek: Ešte ma nevypočuli / Svedok Gorily Holúbek: V súčasnosti je SIS zbytočná firma s aurou tajomnosti. (Holúbek: They Have Not Interviewed Me Yet / Gorilla Witness Holúbek: The SIS is Currently Useles Company With Image of Secrecy.)" Sme, December 28, 24(299): 1, 2-3.

Čikovský, Konštatín (2012): “Analýza: Spis Gorila triafa do reality. (An Analysis: The Gorilla File fits into Reality.)" Sme, January 12, on-line (http://domov.sme.sk/c/6214417/analyza-spis-gorila-triafa-do-reality.html)

Čikovský, Konštatín (2017): “11 rokov Gorily: Ak by si Haščák želal nevyšetrenie, lepší tím ako Kaliňák, Gašpar, Magala a Kováčik by na to nenašiel. (11 Years of Gorilla: If Haščák Would not Like Investigation, He Would Not Find Better Team Than Kaliňák, Gašpar, Magala and Kováčik.)” DennikN, February 15, on-line (https://dennikn.sk/679555/11-rokov-gorily-ak-by-si-hascak-zelal-nevysetrenie-lepsitim-ako-kalinak-gaspar-magala-a-kovacik-by-na-to-nenasiel/

Damijan, Sandra and Jože P. Damijan (2017): Impact of Corruption and Shadow Economy on Macroeconomic Efficiency Losses in Central and Eastern European and Former Soviet Union Economies, VIVES Discussion Paper No 62, November 2017, on-line (https:/ / feb.kuleuven.be/VIVES/publicaties/discussiepapers/dp2017/vivesdiscussion-paper-62-corruption-and-macro-performance)

Daniš, Dag (2015): “Komentár Daga Daniša: Muž, ktorý schoval klúče od kauzy Gorila. (Commentary by Dag Daniš: The man who hid the Key from the Gorilla Case.)" Aktuality, December 11, on-line (http://www.aktuality.sk/clanok/309954/komentardaga-danisa-muz-ktory-schoval-kluce-od-kauzy-gorila/)

Deák, Marko (2013a): “Gorila a test proporcionality. Zablúdil súd pri hl'adaní limitov práva na ochranu osobnosti? (1. čast')" (Gorilla and Proportionality Test. Did the Court Lost Track when Searching for Limits to Right to Protection of Personality?, First part). Justičná revue 65(1): 31-43.

Deák, Marko (2013b): “Gorila a test proporcionality. Zablúdil súd pri hl'adaní limitov práva na ochranu osobnosti? (2. čast')" (Gorilla and Proportionality Test. Did the Court Lost Track when Searching for Limits to Right to Protection of Personality? 2 ${ }^{\text {nd }}$ part). Justićná revue 65(2): 184-200.

Ducák, Martin (2016): "Gorila? Koniec vyšetrovania sa blíži. (Gorilla? The End of Investigation is coming closer.)" Hospodárske noviny, May 10, on-line (https://dennik.hnonline.sk/servisne-prilohy/659893-gorila-koniec-vysetrovania-sa-blizi)

Ďrík, Dušan (2015): “Ako Vagovič oprášil Gorilu a zvolal Heuréka II. (How Vagovič Rediscovered Gorilla and Shouted Euréka II.)", November 16on-line (http://www.kauzagorila.sk/nazory/a139_ako-vagovic-oprasil-gorilu-a-zvolal-heureka-ii)

Fazekas, Mihály and István J.Tóth (2014): From corruption to state capture: A new analytical framework with empirical applications from Hungary, Working Paper Series, CRCBWP/2014:01

Fila, Lukáš (2012b): "Haščák: Gorila je fikcia. (Haščák: The Gorilla is fiction.)" Sme, February 24, on-line (http://www.sme.sk/c/6274248/hascak-gorila-je-fikcia.html)

Fila, Lukáš (2014): "Pät' lekcií z Gorily. (Five lessons from the Gorilla case.)" Sme, September 24, on-line (http:/ / komentare.sme.sk/c/7400556/pat-lekcii-z-gorily.html) 
Grigorescu, Alexandru (2006): "The Corruption Eruption in East-Central Europe: The Increased Salience of Corruption and the Role of Intergovernmental Organizations." East European Politics and Societies 20(3): 516-549, DOI: 10.1177/0888325405276655

Haluza, Ivan (2013, July 11): "Podnikanie s Gorilou za pätami. (Doing business in Gorilla's footprints.)" Trend XXIV(27): 32-37.

Hanus, Martin and Marek Vagovič (2012): "Ten spis je obrazom krajiny. (That File is the Mirror of a Country.)" Ty̌ždeň, January 4, on-line (http://www.tyzden.sk/casopis/ 10352/ten-spis-je-obrazom-krajiny/)

Hellman, Joel S, Geraint Jones and Daniel Kaufmann (2003): "Seize the State, Seize the Day: State Capture and Influence in Transition Economies." Journal of Comparative Economics 31(4): 751-773.

Hrîb, Štefan (2014): “Ako môže .týždeň prežit'. (How Can .týždeň Survive.)” Týž́deň 11(43): 3. Charon, Nicholas (2013): "European Perceptions of Quality of Government: A Survey of 24 Countries." in: A.Mungiu-Pippidi, editor, The Anticorruption Frontline. The Anticorruption Report. Vol.1, Barbara Budrich Publishers: Opladen, 99-120.

Charron, Nicholas, Victor Lapuente and Bob Rothstein (2013): Quality of Government and Corruption from a European Perspective: A Comparative Study of Good Government in EU Regions, Edward Elgar, Cheltenham, UK

Innes, Abby (2014): “The Political Economy of State Capture in Central Europe.” Journal of Common Market Studies 52: 88-104.

Johnston, Michael (2005): Syndromes of Corruption: Wealth, Power and Democracy. Cambridge University Press: Cambridge.

Karklins, Rasma (2002): “Typology of Post-Communist Corruption." Problems of PostCommunism 49(4): 22-32.

Keil, Soeren (2018): "The Business of State Capture and the Rise of Authoritarianism in Kosovo, Macedonia, Montenegro and Serbia." South-Eastern Europe 42(1): 59-82.

Klačanská, Renáta and Zuzana Mezencevová (2012): “Tom Nicholson: Tu žijem, tak sa zaujímam. (Tom Nicholson: I Live Here, Therefore, I Take Interest.)" Život on-line (http://zivot.cas.sk/clanok/10618/tom-nicholson-tu-zijem-tak-sa-zaujimam)

Kostolný, Matúš (2012a): "Prečo sme nepísali o Gorile. (Why We Didn’t Write About the Gorilla.)" Sme, January 18, on-line (http://m.sme.sk/?cl=6222616)

Kostolný, Matúš (2012b): "Radičová: Gorila nie je pravdivá celá. (Radičová: The Gorilla is not Completely True.)" Sme, February 9, on-line (http://www.sme.sk/c/6253753/ radicova-gorila-nie-je-pravdiva-cela.html)

Kováč, Peter (2012): "Komu vyhovovalo zverejnenie Gorily? (Who Could benefit from the publication of the Gorilla files?)" blog.sme.sk, July 27, on-line (http://kovacpeter.blog.sme.sk/c/304344/Komu-vyhovovalo-zverejnenie-gorily.html)

Krajniak, Ignác M. (2015): Banda zlodejov. Šokujúca pravda o oligarchoch a politikoch na Slovensku. (The Gang of Thieves. Shocking Truth About Oligarchs and Politicians in Slovakia), online (http://necenzurovane.net/pdf/banda_zlodejov_1.pdf)

Kupka, Petr and Michal Mocht'ak (2014): "Aféra Nagygate mezi korupcí a organizovaným zločinem: korupční sítě a jejich možný vliv na kvalitu demokracie v České republice. (Nagygate between Corruptio and Organised Crime: Corruption Networks and their Possibly Impact on the Quality of Democracy)" Stredoevropské politické studie / Central European Political Studies Review XVI(4): 237-263. 
Leško, Marián (2016): “Čo je napísané v spise Gorila. (What is written in the Gorilla file.)" Týždeñ, November 27, on-line (https://www.tyzden.sk/casopis/35793/co-jenapisane-v-spise-gorila/)

Maniokas, Klaudijus (2014): “Theoretical approach: Europeanisation, elites, state capture and development." Politologija 76(4): 3-39.

Matuszak, Slawomir (2012): The Oligarchic Democracy: The Influence of Business Groups on Ukrainian Politics. OSW Study 42, Warsaw: OSW Studies

Mihočková, Eva (2015): "Z lyžiarskeho vleku do funkcie. (From the Ski-lift to the Office.)" Plus 7 dni 24: 30-31.

Mungiu-Pippidi, Alina ed. (2014): The Anticorruption Frontline. The Anticorruption Report, vol.2. Opladen - Berlin - Toronto: Barbara Budrich Publishers.

Mungiu-Pippidi, Alina, ed. (2013): Controlling Corruption in Europe. The Anticorruption Report, vol.1. Opladen - Berlin - Toronto: Barbara Budrich Publishers

Murín, Gustáv (2012): Gorily v podsvetí. Mafia.sk, Marenčin PT: Bratislava.

Naxera, Vladimír (2015): "Korupce a postkomunismus. (Corruption and PostCommunism.)" Stredoevropské politické studie 14(2-3): 248-271, on-line (https://journals.muni.cz/cepsr/article/view/4583)

Nicholson, Tom (2009): "Bribery scandal reopened." The Slovak Spectator, February 19, on-line (https://spectator.sme.sk/c/20031824/bribery-scandal-reopened.html)

Nicholson, Tom (2012): Gorila. Bratislava: Dixit.

Nôta, Peter (2015): "Zabudnite na Gorilu. (Forget About Gorilla)" Dennik N, August 8, on-line (https://dennikn.sk/blog/zabudnite-na-gorilu/?ref=box)

Obradovič, Filip and Zuzana Petková (2014): "Slovensko v moci oligarchov. (Slovakia in the hands of oligarchs)" Trend, December 18, XXIV(50-51): 11-15.

Okáli, Ivan (2006): “Celkový pohl’ad na hospodársky vývoj v roku 2005. (The Global View on Development of Economy)", in: I. Okáli (ed.), Hospodársky vývoj Slovenska v roku 2005. Bratislava: Slovak Academy of Sciences, 5-13, on-line (http://ekonom.sav.sk/ uploads/journals/51_hv_sr_2005_-_slovenska_verzia.pdf)

Olszański, Tadeusz A. (2017): “A quarter-century of independent Ukraine. Dimensions of transformation." Number 64, Warsaw, OSW Studies

Penta Investments (2016): “Ako informuje o Pente Denník N? Zaujato, ukázala analýza. (How Does Denník N Report on Penta? In a Biased Way, as Shown in the Analysis.)" Aktuálne, on-line (http://www.kauzagorila.sk/aktualne/a231_ako-informuje-o-pentedennik-n-zaujato-ukazala-analyza)

Petková, Zuzna (2012): "Nicholson: Núkali mi milióny, ak na Gorilu zabudnem. (Nicholson: They Were Offering Millions to Me, if I Forget About the Gorilla.)" Sme, January 1, on-line (http://www.sme.sk/c/6200787/nicholson-nukali-mi-miliony-ak-nagorilu-zabudnem.html)

Philp, Mark (2001): Corruption and State Capture: An Analytical Framework, paper presented at workshop on state-capture and the public/private interface for the IACC Meeting in Prague, October 2001

Porta, Donatella and Alberto Vanucci (1999): Corrupt Exchanges: Actors, Resources, and Mechanisms of Political Corruption, Transaction Publishers.

Prušová, Veronika and Lukáš Fila (2012): “Lipšic: Strany mali tichú dohodu o zametaní korupcie. (Lipšic: The Parties Had a Tacit Agreement About the Corruption Sweep)." 
Sme, January 25, on-line (http://www.sme.sk/c/6232274/lipsic-strany-mali-tichudohodu-o-zametani-korupcie.html)

Remler, Dahlia K. and van Ryzin, Gregg G. (2015): Research Methods in Practice. Strategies for Description and Causation. 2nd ed., L.A.: Sage.

SITA (The Slovak Press Agency) (2012): "Lipšic zriadil špeciálny tím na vyšetrovanie kauzy Gorila. (Lipšic set up a special team for investigating the Gorilla case.)" Pravda, January 9, on-line (http://spravy.pravda.sk/domace/clanok/172960-lipsic-zriadilspecialny-tim-na-vysetrovanie-kauzy-gorila/)

Stake, Robert E. (1995): The Art of Case Study Research. London: Sage.

Staroňová, Katarína and Ludmila Malíková (2007): "Pohlad politológie na fenomén korupcie. (Political Science Approach towards the Study of Corruption.)" Sociologia Slovak Sociological Review 39(4): 287-315.

Steves, Franklin and Alan Rousso (2003): Anti-corruption programmes in post-communist transition countries and changes in the business environment, 1999-2002. EBRD Working paper No. 85.

Svoráková, Soňa (2012): “Rok Gorily. (The Year of Gorilla).” Politické vedy 15(4): 95-107. Šátek, Jozef (2010): "Vláda slovenskej finančnej oligarchie (The Governance of Slovak Financial Oligarchy)." blog.sme.sk, May 26, on-line (http://satek.blog.sme.sk/c/229906/ Vlada-slovenskej-financnej-oligarchie.html)

Šátek, Jozef (2012a): "Gorila ako King-Kong I. (Gorilla aka King-Kong I.)” blog.sme.sk, January 1, on-line (http://satek.blog.sme.sk/c/285872/Gorila-ako-King-Kong-I.html)

Šátek, Jozef (2012b): "Gorila ako King-Kong II. (Gorilla aka King-Kong II.)” blog.sme.sk, January 1, on-line (http://satek.blog.sme.sk/c/285970/Gorila-ako-King-Kong-II.html)

Šátek, Jozef (2012c): "Takto chcú "vyšetrovat" Gorilu? (Is this the Way they Intend to "Investigate" Gorilla?")" blog.sme.sk, March 23, on-line (http://satek.blog.sme.sk/c/ 294147/Takto-chcu-vysetrovat-Gorilu.html)

Škubla, Martina (2016): "Súmrak Gorily? (The Dawn of Gorilla?)" kauragorila.sk, January 26, on-line (http://www.kauzagorila.sk/nazory/a187_sumrak-gorily)

Tódová, Martina (2015a): 'Svedok Gorily chcel vypovedat', Kováćik to stopol a umlčal šéfa policajného tímu (The Witness in the Gorilla Case Wanted to Testify, Kováčik Stopped it and Made the Head of the Police Squad Silent)." Dennik N, August 15, on-line (https://dennikn.sk/95706/specialny-prokurator-kovacik-zabranil-vypocutiu-svedkov-gorily/)

Tódová, Martina (2015b): "Anonym zverejnil Gorilu 2, rozhovory bývalého šéfa kontrarozviedky Arpáša. (Gorilla 2 Was Published Anonymously, the Conversations of the Former Counter-Intelligence Service's Head Arpáś.)" Dennik N, November 20, online (https://dennikn.sk/300440/anonym-zverejnil-gorilu-2-rozhovory-byvaleho-sefakontrarozviedky-arpasa/?ref $=$ tit)

Tódová, Martina (2015c): “Arpáš, ktorý mal predat' Pente Gorilu, priznal: Informácie som odovzdával Lorencovi. (Arpáś, Who Supposedly Sold the Gorilla to Penta, Confessed: I Was Handing the Information Over to Lorenc.)" Dennik N, November 5, on-line (https://dennikn.sk/287224/arpas-ktory-mal-predat-pente-gorilu-informacieodovzdaval-lorencovi/)

Tódová, Martina (2017): “Vyšetrovatel’ Gorily Gajdoš: Vidím, kol'ko komu Penta poslala na účet, ale neviem dokázat', že to je úplatok. (Police Investigator Gajdoš: I See How Much and to Whom Has Penta Sent (Money), But I Can Not prove That it Was a Bribe.)" 
Dennik N, January 11, on-line (https://dennikn.sk/653316/vysetrovatel-gorily-gajdosvidim-kolko-komu-penta-poslala-na-ucet-ale-neviem-dokazat-ze-to-je-uplatok/?ref=tit)

Vagovič, Marek (2015): “Ked’ Kováčik naháňa Gorilu. (When Kováčik Runs After Gorilla.)" Týždeň, June 21, on-line (http://www.tyzden.sk/casopis/17703/ked-kovaciknahana-gorilu/)

Vagovič, Marek (2016): Vlastnou blavou: ako predal Fico krajinu oligarchom (Thanks to his own efforst: How Fico sold the country to oligarchs). Premedia: Bratislava.

Vagovič, Marek (2016): “Autor spisu Gorila Peter Holúbek: SIS je úplne deravá. Robia tam obchodníci. (Author of Gorilla File Peter Holúbek: SIS is totally Corrupted. There are Businessmen at Work.)" Aktuality, February 22, on-line (http://www.aktuality.sk/ clanok/314837/autor-spisu-gorila-peter-holubek-sis-jeuplne-derava-robia-tam-obchodnici/)

Vagovič, Marek (2017): "Bývalý šéf tímu Gorila Marek Gajdoš: Urobili zo mňa nepriatel’a štátu. (Marek Gajdoš, former head of Gorilla Investigating Team: They have made out of me an enemy of the State.)" Aktuality, January 11, on-line (https://www.aktuality.sk/clanok/403915/byvaly-sef-timu-gorila-marek-gajdos-urobilizo-mna-nepriatela-statu/)

Valček, Adam (2015a): “Nahrávky z Gorily Haščákovi nedajú pokoj. Mali byt' dávno zničené, aj tak chce ich zákaz. (Recordings from Gorilla Make Worries to Haščák. They Were Supposed to be Destroyed a Long Time Ago, Nevertheless, He Pushes for Their Legal Ban.)" Trend, February 2, on-line (http://www.etrend.sk/ekonomika/nahravky-zgorily-hascakovi-nedaju-pokoj-mali-byt-davno-znicene-aj-tak-chce-ich-zakaz.html), (http://www.etrend.sk/ekonomika/nahravky-z-gorily-hascakovi-nedaju-pokoj-malibyt-davno-znicene-aj-tak-chce-ich-zakaz.html)

Valček, Adam (2015b): "Penta podala d’alšie žaloby na Denník N. (Penta has Filed Another Suit Against the Daily Denník N.)" Sme, October 3, on-line (http://ekonomika.sme.sk/c/8024222/penta-podala-dalsie-zaloby-na-dennik-n.html)

Valček, Adam (2016): "Súd: Sledovanie majitel'a bytu z Gorily nebolo v poriadku. (The Court: Wiretapping Operation of the Owner of an Apartment in Gorilla was not Legally Justified.)" Sme, February 4, on-line (http://domov.sme.sk/c/20086259/sudsledovanie-majitela-bytu-z-gorily-nebolo-v-poriadku.html\#ixzz48WSS6WgP)

Wágner, František (2017): “Dezinformácie v kauze Gorila. (Misleading Information in the Gorilla Case.)" blog.sme.sk, January 13, on-line (http://frantisekwagner2.blog.sme.sk/c/ 444277/dezinformacie-v-kauze-gorila.html)

World Bank (2000): Anticorruption in Transition: Confronting the Challenge of State Capture. Washington, D.C.:World Bank Publications.

Yin, Rober K. (2013): Case Study Research: Design and Methods. $5^{\text {th }}$ edition. London: SAGE 